\title{
Treatability Study on The Use of By-product Sulfur In Kazakhstan For The Stabilization of Hazardous And Radioactive Wastes
}

\author{
P.D. Kalb ${ }^{1}$, L.W. Milian ${ }^{1}$, S.P. Yim ${ }^{2}$, R.S. Dyer ${ }^{3}$, and W.R. Michaud ${ }^{3}$ \\ ${ }^{1}$ Brookhaven National Laboratory \\ ${ }^{2}$ Korean Atomic Energy Research Institute \\ ${ }^{3}$ U.S. Environmental Protection Agency
}

Environmental Sciences Department

Brookhaven National Laboratory

Brookhaven Science Associates

Upton, Long Island New York 11973

Under Contract No. DE-AC02-98CH10886 with the

UNITED STATES DEPARTMENT OF ENERGY 


\title{
DISCLAIMER
}

This report was prepared as an account of work sponsored by an agency of the United States Government. Neither the United State Government nor any agency thereof, nor any of their employees, not any of their contractors, subcontractors, or their employees, makes any warranty, express or implied, or assumes any legal liability or responsibility for the accuracy, completeness, or usefulness of any information, apparatus, product, or process disclosed, or represents that its use would not infringe privately owned rights. Reference herein to any specific commercial product, process, or service by trade name, trademark, manufacturer, or otherwise, does not necessarily constitute or imply its endorsement, recommendation, or favoring by the United States Government or any agency, contractor, or subcontractor thereof. The vies and opinions of authors expressed herein do not necessarily state or reflect those of the United States Government or any agency, contractor or subcontractor thereof.

\author{
Printed in the United States of America \\ Available from \\ National Technical Information Service \\ U.S. Department of Commerce \\ 5285 Port Royal Road \\ Springfiled, VA 22161
}





\title{
Treatability Study on The Use of By-product Sulfur In Kazakhstan For The Stabilization of Hazardous And Radioactive Wastes*
}

\author{
P.D. Kalb ${ }^{1}$, L.W. Milian ${ }^{1}$, S.P. Yim², R.S. Dyer ${ }^{3}$, and W.R. Michaud ${ }^{3}$ \\ ${ }^{1}$ Brookhaven National Laboratory \\ ${ }^{2}$ Korean Atomic Energy Research Institute \\ ${ }^{3}$ U.S. Environmental Protection Agency
}

\section{ABSTRACT}

The Republic of Kazakhstan generates significant quantities of excess elemental sulfur from the production and refining of petroleum reserves. In addition, the country also produces hazardous and radioactive wastes which require treatment/stabilization. In an effort to find secondary uses for the elemental sulfur, simultaneously produce a material which could be used to encapsulate, and reduce the dispersion of harmful contaminants into the environment, BNL evaluated the use of the sulfur polymer cement (SPC) produced from by-product sulfur in Kazakhstan. This thermoplastic binder material forms a durable waste form with low leaching properties and is compatible with a wide range of waste types. Several hundred kilograms of Kazakhstan sulfur were shipped to the U.S. and converted to SPC (by reaction with 5 weight percent (wt\%) organic modifiers for use in this study. A phosphogypsum sand waste generated in Kazakhstan during the purification of phosphate fertilizer was selected for treatment. Waste loadings of $40 \mathrm{wt} \%$ were easily achieved. Waste form performance testing included compressive strength, water immersion, and Accelerated Leach Testing.

\section{INTRODUCTION}

Chevron Oil Corp., together with the Kazakhstan Ministry of Oil and Gas, has formed a partnership (Tengizchevroil) to explore, develop, and market oil and gas reserves in the Tengiz region of Kazakhstan on the northern shore of the Caspian sea. The growing oil industry in Kazakhstan is already one of their major industries. However, due to limited resources and the required infrastructure to manage resulting toxic and hazardous wastes, there is a growing potential for environmental consequences arising from oil production, refining operations and other environmentally sensitive industries that will need to be addressed. This project, sponsored by the U.S. Environmental Protection Agency Office of International Activities, is investigating potential environmental solutions to foster both commercial and environmental sustainable development in Kazakhstan.

Large quantities of by-product sulfur are currently generated by the cleanup of hydrogen sulfide in the production of petroleum and natural gas at the Tengizchevroil fields in Kazakhstan. Currently about 1,200 metric tons/day of sulfur are generated from processing 60,000 barrels of oil/day, but oil production is

${ }^{*}$ This work was performed under the auspices of the U.S. Department of Energy. 
expected to grow rapidly. The by-product sulfur has little commercial or social benefit and presently, much of it is disposed as waste. Tengizchevroil has obtained special permission from the Kazakhstan Ministry of the Environment to "block and store" the sulfur by-product, a process in which the molten sulfur is cooled into large solid blocks for storage. But as the volume of sulfur residue increases with increased oil and gas production, this practice may no longer be sound or acceptable. In addition, hazardous oil and gas residuals (e.g., incinerator ash, blowdown solutions), as well as toxic and hazardous wastes generated by other past, currently operating and emerging industries throughout Kazakhstan are produced and require treatment prior to disposal.

This paper evaluates the feasibility of using sulfur polymer (produced from by-product sulfur in the Tengiz region of Kazakhstan) to encapsulate hazardous and radioactive wastes generated on site, at other sites in Kazakhstan, and elsewhere in eastern Europe. Phosphogypsum sand waste generated in Kazakhstan from the production of fertilizers was used for this treatability study. This waste was characterized, encapsulated in sulfur polymer and subjected to selected standardized performance tests (e.g., NRC, ASTM) to evaluate mechanical integrity, durability, and leaching properties.

\section{SULFUR POLYMER ENCAPSULATION}

Using techniques developed by the U.S. Bureau of Mines $[1,2]$ by-product sulfur can be successfully converted into a stable, durable alternative to concrete with numerous environmental and commercial applications including stabilization of toxic and hazardous wastes. The sulfur is reacted with an organic oligomer (e.g., dicyclopentadiene) and other polymers to form a thermoplastic material known as sulfur polymer or SPC with mechanical properties and chemical durability greater than conventional cement products. Its strength and resistance to harsh chemical environments makes sulfur polymer useful for encapsulation of radioactive, hazardous and mixed wastes, as well as for general construction, paving, piping, and coatings for tanks and pads. Since the processing temperature of SPC is relatively low (melting temperature of $120^{\circ} \mathrm{C}$ ) compared with thermal processes such as vitrification (process temperatures in excess of $1200^{\circ} \mathrm{C}$ ), volatization of contaminants is minimized or eliminated. The commercial cost of sulfur polymer produced in the U.S. is about $\$ 0.12 / \mathrm{lb}$., but due to the large inventory of waste sulfur and low operating expenses, the anticipated cost in Kazakhstan would be lower.

The application of sulfur polymer for encapsulating radioactive, hazardous, and mixed wastes was developed over the last 10 years at the BNL Environmental and Waste Technology Center under sponsorship of the U.S. DOE [3-9]. The process uses a heated double planetary orbital mixer to heat and melt the waste and sulfur polymer binder to form a homogeneous molten mixture. The mixture is then poured into suitable molds for cooling to a solid monolithic final waste form. Contrary to conventional cement processes, the sulfur polymer encapsulation process does not rely on a chemical reaction for hardening, so it is more compatible with a wide range of waste types and can accept greater volumes of waste. Thus, overall waste volumes for storage and disposal are reduced and treatment costs are significantly decreased.

The process has been successfully applied to a wide range of waste types including evaporator concentrates, ash, and sludges. Improved waste loadings have been achieved while still exceeding waste form performance standards specified by the U.S. Nuclear Regulatory Commission (NRC) and U.S. Environmental Protection Agency (EPA). A process flow diagram of the sulfur polymer microencapsulation process is shown in Figure 1. 


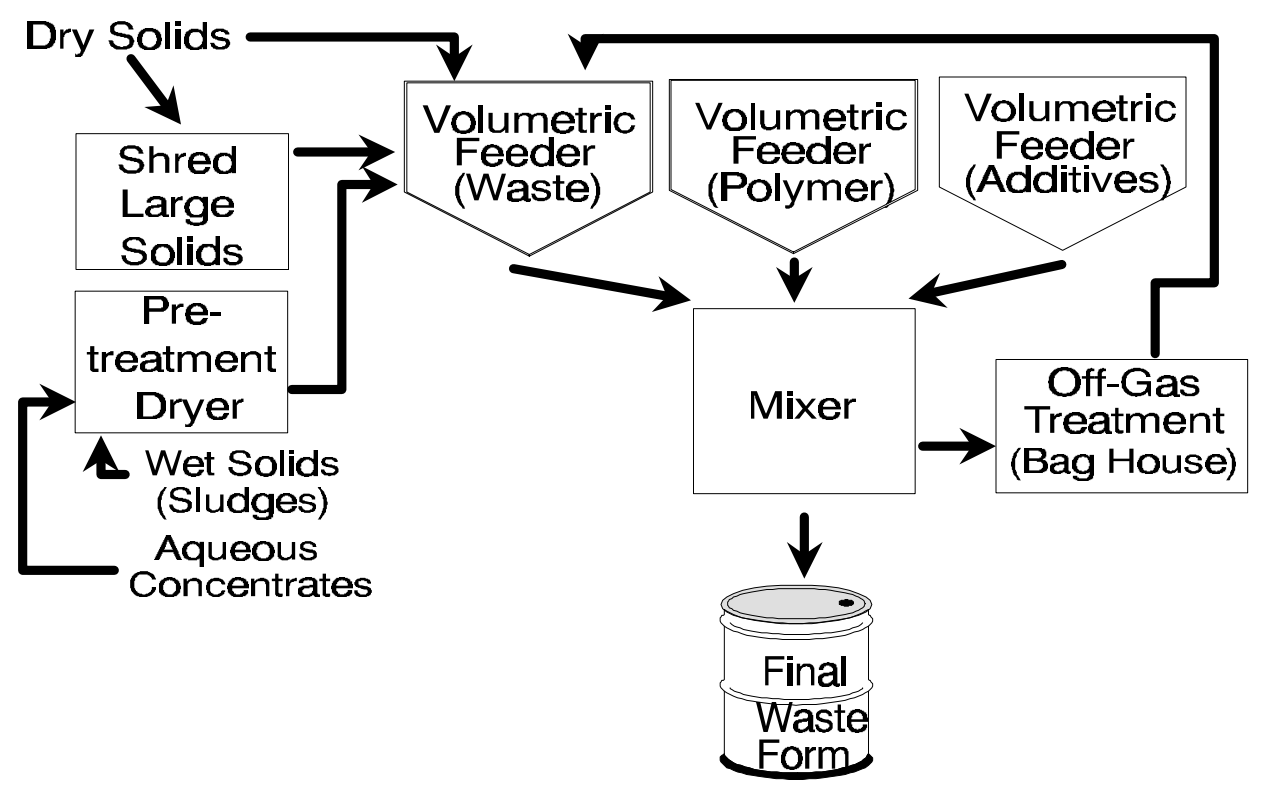

Figure 1. Sulfur Polymer Encapsulation Process Flow Diagram

\section{KAZAKHSTAN SULFUR}

Twelve drums containing approximately $44 \mathrm{~kg}$. each of by-product elemental sulfur were shipped to the U.S. by Tengizchevroil in Kazakhstan. Six drums of the Kazakhstan sulfur were shipped to McBee and Associates (Lebanon, OR) for conversion to SPC. The material was reacted in a 15-gallon stainless steel, steam-jacketed reactor at a temperature of $140^{\circ} \mathrm{C}$. The molten sulfur was reacted with a mixture of 2.5 $\mathrm{wt} \%$ polyester grade dicyclopentadiene and $2.5 \mathrm{wt} \%$ of a proprietary reactive polymer manufactured by Exxon Chemical Co. The reaction was conducted for about 4 hours until a viscosity of 50 centipoise, measured at $135^{\circ} \mathrm{C}$ was achieved. The molten SPC material was then cooled and solidified in 5 gallon steel containers for shipment. Unlike commercially available SPC which is marketed in flaked or granular form, the SPC was received in large blocks from which smaller quantities were chipped off as needed for processing.

Small representative samples of the source sulfur and the SPC produced from Kazakhstan sulfur were analyzed for purity by ACTLABS, Inc., using ICP, INAA, ICP/MS, and XRF techniques. Results are summarized in Table 1. Comparison of carbon content before ( $<3 \mathrm{ppm})$ and after conversion to SPC $(5$ wt \%) indicates that the organic polymer modification was accomplished successfully. The source sulfur and the SPC contained a small quantity of chromium which is defined by the EPA as a toxic metal. However, leach testing of these materials according to the EPA Toxicity Characteristic Leaching Procedure (TCLP) [10] resulted in concentrations of chromium ( $0.05 \mathrm{ppm})$ below the allowable limit (5 $\mathrm{ppm}$ ) that define a characteristic hazardous waste. 
Table 1. Chemical Analysis of Kazakhstan Sulfur and Sulfur Polymer

\begin{tabular}{|c|c|c|}
\hline Element & $\begin{array}{c}\text { Concentration in } \\
\text { Elemental Sulfur, } \\
\text { ppm }\end{array}$ & $\begin{array}{c}\text { Concentration in } \\
\text { Sulfur Polymer, } \\
\text { ppm }\end{array}$ \\
\hline $\mathrm{Ag}$ & $<0.5$ & $<0.5$ \\
\hline $\mathrm{Al}_{2} \mathrm{O}_{3}$ & 300 & 300 \\
\hline As & $<1$ & $<1$ \\
\hline $\mathrm{Ba}$ & 7 & 6 \\
\hline $\mathrm{Be}$ & $<2$ & $<2$ \\
\hline $\mathrm{Bi}$ & $<5$ & $<5$ \\
\hline $\mathrm{Br}$ & $<0.5$ & $<0.5$ \\
\hline $\mathrm{CaO}$ & $<100$ & $<100$ \\
\hline $\mathrm{Cd}$ & $<0.5$ & $<0.5$ \\
\hline Co & 0.8 & 1.1 \\
\hline $\mathrm{Cr}$ & 6.9 & 11.9 \\
\hline Cs & $<0.2$ & $<0.2$ \\
\hline $\mathrm{Cu}$ & 5 & 6 \\
\hline $\mathrm{Fe}_{2} \mathrm{O}_{3}$ & 300 & 200 \\
\hline $\mathrm{Hf}$ & $<0.2$ & $<0.2$ \\
\hline Ir & $<0.001$ & $<0.001$ \\
\hline $\mathrm{K}_{2} \mathrm{O}$ & $<100$ & $<100$ \\
\hline $\mathrm{MgO}$ & 100 & 400 \\
\hline $\mathrm{MnO}$ & $<100$ & $<100$ \\
\hline Mo & $<2$ & $<2$ \\
\hline $\mathrm{Na}_{2} \mathrm{O}$ & $<100$ & $<100$ \\
\hline $\mathrm{Ni}$ & 3 & 3 \\
\hline $\mathrm{P}_{2} \mathrm{O}_{5}$ & $<100$ & $<100$ \\
\hline $\mathrm{Pb}$ & $<5$ & $<5$ \\
\hline $\mathrm{Rb}$ & $<10$ & $<10$ \\
\hline $\mathrm{Sb}$ & $<0.1$ & $<0.1$ \\
\hline $\mathrm{Se}$ & $<0.5$ & $<0.5$ \\
\hline $\mathrm{SiO}_{2}$ & 1,400 & 2,700 \\
\hline $\mathrm{Sr}$ & $<1$ & $<1$ \\
\hline $\mathrm{Ta}$ & $<0.3$ & $<0.3$ \\
\hline $\mathrm{TiO}_{2}$ & $<100$ & $<100$ \\
\hline $\mathrm{V}$ & $<2$ & $<2$ \\
\hline $\mathrm{W}$ & $<1$ & $<1$ \\
\hline $\mathrm{Y}$ & $<2$ & $<2$ \\
\hline $\mathrm{Zn}$ & 5 & 7 \\
\hline $\mathrm{Zr}$ & 3 & 3 \\
\hline
\end{tabular}




\begin{tabular}{|l|r|r|}
\hline Element & $\begin{array}{c}\text { Concentration in } \\
\text { Elemental Sulfur, } \\
\mathrm{ppm}\end{array}$ & $\begin{array}{c}\text { Concentration in } \\
\text { Sulfur Polymer, } \\
\mathrm{ppm}\end{array}$ \\
\hline $\mathrm{Sc}$ & $<0.01$ & 0.01 \\
\hline $\mathrm{La}$ & 0.2 & 0.2 \\
\hline $\mathrm{Ce}$ & 1 & 2 \\
\hline $\mathrm{Nd}$ & $<1$ & 4 \\
\hline $\mathrm{Sm}$ & 0.03 & 0.05 \\
\hline $\mathrm{Eu}$ & $<0.05$ & $<0.05$ \\
\hline $\mathrm{Tb}$ & $<0.1$ & $<0.1$ \\
\hline $\mathrm{Yb}$ & $<0.05$ & 0.06 \\
\hline $\mathrm{Lu}$ & $<0.01$ & $<0.01$ \\
\hline $\mathrm{U}$ & $<0.1$ & $<0.1$ \\
\hline $\mathrm{Th}$ & $<0.1$ & 0.1 \\
\hline $\mathrm{C}$ & $<3$ & 50,020 \\
\hline
\end{tabular}

\section{CHARACTERISTICS OF PHOSPHOGYPSUM SAND WASTE}

Phosphogypsum sand was selected for encapsulation in SPC because of its availability and potential hazards associated with the by-product material. In addition to being relatively acidic and containing small amounts of fluoride, the material has been determined to be slightly radioactive. Analyses performed on phoshogypsum stockpiled in Florida have shown radium contents between $20-30 \mathrm{pCi} / \mathrm{g}$. This compares with natural gypsum where the radium content of most soils and rocks is $<2 \mathrm{pCi} / \mathrm{g}$. The daughter products of radium decay are of equal concern (Radon gas, $\mathrm{Pb}-210$, and Po-210). As a result, the large-scale uses (road construction and agriculture) of phosphogypsum has in part, been prohibited by the EPA because of the elevated levels of these radionuclides.

Analyses of phosphogypsum sand waste received from Kazakstan were conducted to determine density, moisture content, acidity in water, particle size, elemental composition, and radionuclides. Density was measured at room temperature using a Multi Pycnometer MVP-1 (Quantachrome Co.). Moisture content was determined at $105^{\circ} \mathrm{C}$ using a Moisture Analyzer MA30 (Sartorius Co.). Acidity in water was obtained by soaking $1 \mathrm{~g}$ of the sand into the $10 \mathrm{ml}$ of demineralized water and measuring the $\mathrm{pH}$ of the supernatant water after 24 hours. Particle size distribution was analyzed using ASTM standard sieves according to ASTM C136-80. After $1 \mathrm{~g}$ of phosphogypsum sand waste was dissolved in $30 \mathrm{ml}$ of acid solution (conc. $\mathrm{HCl}$ : conc. $\mathrm{HNO}_{3}=1: 1$ ), elemental composition of dissolved solution were analyzed for various elements by Inductively Coupled Plasma-Atomic Emission Spectroscopy (ICP). Non-dissolved material was filtered and weighed after drying at $110^{\circ} \mathrm{C}$. The concentration of phosphorus in dissolved solution was measured using a Hatch kit (Hach Co.).

The properties of phosphogypsum sand waste are summarized in Table 2. The elemental composition of phospogypsum sand waste is presented in Table 3. Particle size distribution of waste is shown in Figure 2. 
The moisture content of the "as-received" phosphogypsum sand waste was 12.3 wt $\%$. The waste was then dried by heating overnight in a convection oven at $110^{\circ} \mathrm{C}$, prior to encapsulation in SPC. Dried waste was encapsulated in SPC directly without any size screening or size reduction because the content of relatively large particles (>2 mm) was less than $4 \mathrm{wt} \%$. The major elements of phosphogypsum sand waste were calcium, phosphorus, iron, and aluminum. Non-dissolved materials in acid solution may be silicon compounds. Hazardous (toxic) elements are not present in the waste in significant quantities. In addition to analysis for non-radioactive elements, radionuclides analysis was conducted qualitatively by counting $100 \mathrm{~g}$ of sample for 24 hours on an intrinsic Ge gamma-spectrometer (with a Canberra computer system). However, no evidence was found for the existence of any radionuclides other than background levels of natural uranium. Although analyses on elements and radionuclides revealed no toxic and radioactive constituents, handling and disposal of this material may provide environmental concerns due to dispersibility.

Table 2. Properties of Phosphogypsum Sand Waste

\begin{tabular}{|l|c|}
\hline \multicolumn{1}{|c|}{ Property } & Value \\
\hline Density, g/cm ${ }^{3(\mathrm{a})}$ & 2.57 \\
\hline Moisture Content, wt\% & 12.3 \\
\hline Acidity in Water, $\mathrm{pH}$ & 5.1 \\
\hline Non-Dissolved Materials in Acid Solution, wt\% ${ }^{\text {(b) }}$ & 7.4 \\
\hline
\end{tabular}

(a) Density measured by Multi-Pycnometer after drying at $105{ }^{\circ} \mathrm{C}$.

(b) Acid solution(conc. $\mathrm{HCl}$ :conc. $\mathrm{HNO}_{3}=1: 1$ ). 
Table 3. Elemental Composition of Phosphogypsum Sand Waste

\begin{tabular}{|c|c|}
\hline Element & Concentration, ppm \\
\hline $\mathrm{Al}$ & 4,754 \\
\hline $\mathrm{Ba}$ & 210.4 \\
\hline $\mathrm{Ni}$ & 8.9 \\
\hline $\mathrm{Fe}$ & 5,390 \\
\hline $\mathrm{Cr}$ & 5.1 \\
\hline $\mathrm{Zn}$ & 27.3 \\
\hline $\mathrm{Cu}$ & 32.7 \\
\hline $\mathrm{Cd}$ & - \\
\hline $\mathrm{Ca}$ & 45,770 \\
\hline $\mathrm{Sr}$ & 2,515 \\
\hline $\mathrm{Mg}$ & 377.6 \\
\hline $\mathrm{Na}$ & 1,703 \\
\hline $\mathrm{K}$ & 2,512 \\
\hline $\mathrm{Rb}$ & 598.1 \\
\hline As & 103.6 \\
\hline $\mathrm{Se}$ & 9.7 \\
\hline $\mathrm{Ti}$ & 52.4 \\
\hline $\mathrm{Mn}$ & 24.5 \\
\hline $\mathrm{Sb}$ & 68.8 \\
\hline $\mathrm{Mg}$ & 421.3 \\
\hline Mo & 7.2 \\
\hline $\mathrm{Pb}$ & 1.0 \\
\hline $\mathrm{V}$ & 1.2 \\
\hline $\mathrm{P}$ & 9,350 \\
\hline
\end{tabular}




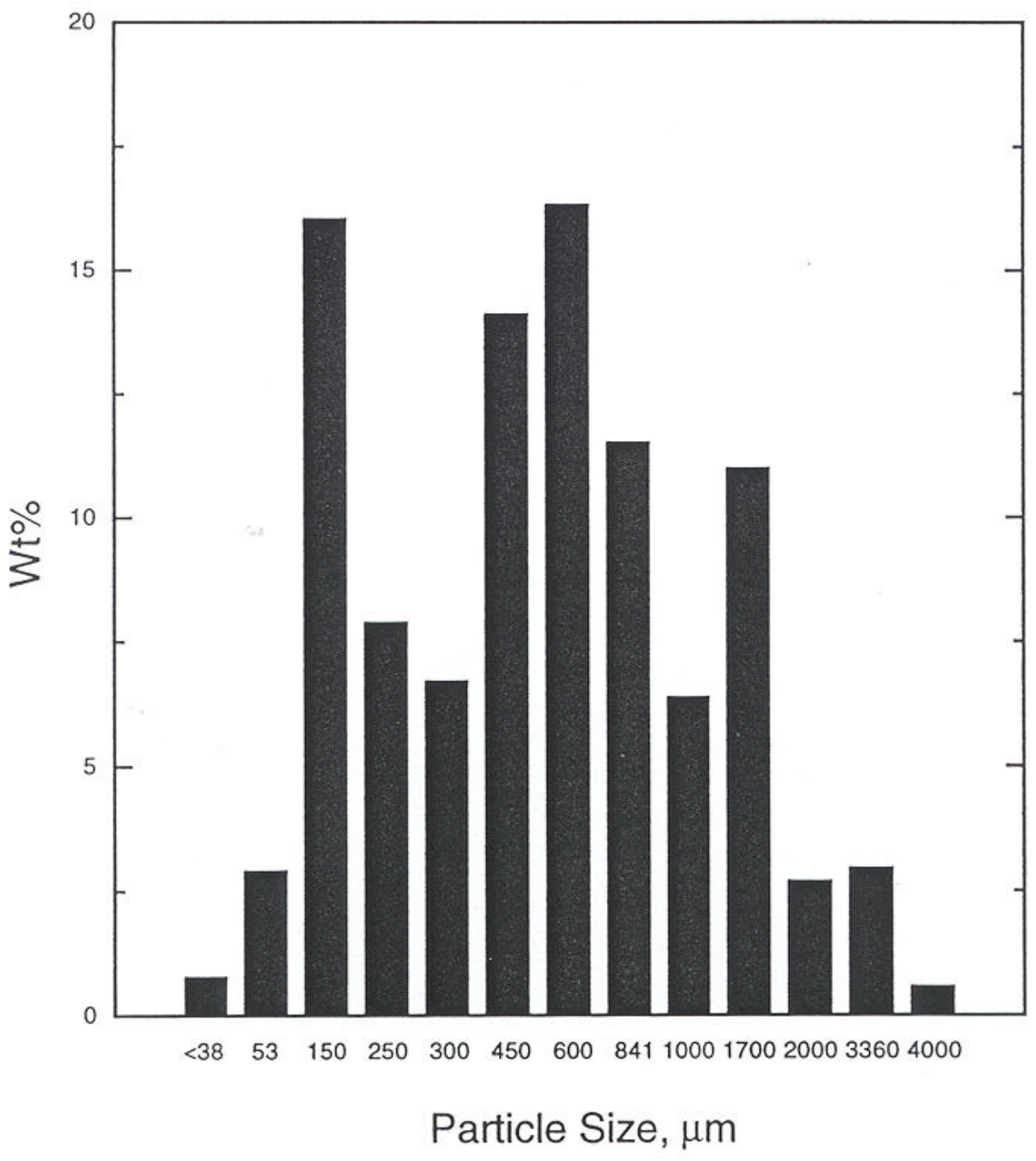

Figure 2. Particle Size Distribution of Phosphogypsum Sand Waste 


\section{DETERMINATION OF OPTIMUM LOADING WITH SURROGATE}

Only a limited supply of the Kazakhstan phosphogypsum sand waste was available for this study. Therefore, waste form loading optimization was performed using calcium sulfate reagent as a surrogate for Kazakhstan phosphogypsum sand waste. Surrogate calcium sulfate was a fine powder of $\mathrm{CaSO}_{4} \cdot 1 / 2 \mathrm{H}_{2} \mathrm{O}$ (calcium hemihydrate). Its density and moisture content were $2.61 \mathrm{~g} / \mathrm{cm}^{3}$ and $5.6 \mathrm{wt} \%$, respectively. It was dried at $110^{\circ} \mathrm{C}$ prior to encapsulation. The density of the dry powder was 2.613 $\mathrm{g} / \mathrm{cm}^{3}$.

SPC waste forms were formulated using an electrically heated, stirred mixer by: (1) heating of the SPC at $130^{\circ} \mathrm{C}$ until the SPC has completely melted, (2) adding dry surrogate to molten SPC and mixing the constituents into a homogeneous slurry by mixer, and (3) pouring into a suitable mold and cooling to a monolithic solid. Formulations were prepared with increasing quantities of waste until the limits of processibility were reached.

SPC waste forms containing 10, 15, 20, 30, 40, 50, and $56 \mathrm{wt} \%$ surrogate calcium sulfate were prepared according to above mentioned steps. Above $50 \mathrm{wt} \%$ surrogate, the molten SPC and surrogate mixture was so viscous that it hardly flowed to the mold. Maximum loading of surrogate determined by the limit of processibility in this experiment was $56 \mathrm{wt} \%$. The molten mixtures containing 30 and $40 \mathrm{wt} \%$ surrogate, respectively, had a good fluidity and homogeneity at $130^{\circ} \mathrm{C}$. The waste forms were also homogeneous after cooling. In the mixtures containing 10, 15 and $20 \mathrm{wt} \%$ surrogate, some of the particles of surrogate seemed agglomerate in the melted sulfur.

All waste forms prepared with the surrogate waste were immersed in water and were observed for changes in their physical appearance over a period of 90 days. SPC waste forms containing $50 \mathrm{wt} \%$ and $56 \mathrm{wt} \%$ surrogate cracked within 2 weeks and 1 week, respectively. The other waste forms maintained their original forms after 90 days.

As a result of processibilty and immersion tests, optimum loading of surrogate calcium sulfate was determined at the range of 30-40 wt $\%$ in the SPC waste form.

\section{WASTE FORM PERFORMANCE}

\subsection{Sample Preparation}

Based on determination of optimum loading with surrogate, SPC waste forms containing $40 \mathrm{wt} \%$ Kazakhstan phosphogypsum sand waste were prepared by the same steps and conditions described above. The molten mixture of SPC and waste was poured into a PVC tube measuring $1.6^{\prime \prime}$ in diameter by $3^{\prime}$ in height. The same molten mixture was also poured into another PVC tube measuring $1^{\prime \prime}$ in diameter by $1^{\prime}$ in height. After cooling to ambient temperature, they were cut into specimens measuring 1.6" in diameter by $3.2^{\prime \prime}$ in height and $1^{\prime \prime}$ in diameter by $1^{\prime \prime}$ in height, respectively, within 7 days. Eight specimens measuring $1.6^{\prime \prime}$ in diameter by $3.2^{\prime \prime}$ in height and five specimens measuring $1^{\prime \prime}$ in diameter by 1 " in height were obtained. Of the eight specimens measuring $1.6^{\prime \prime}$ in diameter by $3.2^{\prime \prime}$ in height, four specimens were used in the compressive strength testing and another three specimens were used in water immersion testing. The last specimen was cross-sectioned for observation. Three of five samples measuring 1 " in diameter 
by $1^{\prime \prime}$ in height were used in an accelerated leach test (ALT) and the other two samples were archived. SPC waste forms containing $40 \mathrm{wt} \%$ surrogate calcium sulfate were prepared in the same fashion. Compressive strength testing, water immersion testing, and ALT were performed on SPC waste form specimens containing surrogate as well as on SPC waste form specimens containing actual phosphogypsum sand waste.

\subsection{Homogeneity}

A thorough homogenization of waste within the solidified waste form is desirable so that the waste form will exhibit uniform performance characteristics. As a measure of homogeneity, the apparent density of waste form was obtained for all specimens by dividing the weight of the waste form by the volume calculated from the form dimensions. Apparent densities for the specimens measuring $1.6^{\prime \prime}$ in diameter by $3.2^{\prime \prime}$ in height are presented in Table 4.

Table 4. Apparent Densities of SPC Waste Forms Containing 40 wt\% Waste

\begin{tabular}{|c|c|c|}
\hline & \multicolumn{2}{|c|}{ Apparent Density of SPC Waste Form, g/cm ${ }^{3}$} \\
\hline Sample Number & Phosphogypsum Sand Waste & Surrogate Calcium Sulfate \\
\hline$\# 1$ & 1.908 & 2.068 \\
\hline$\# 2$ & 1.893 & 2.052 \\
\hline$\# 3$ & 1.897 & 2.070 \\
\hline$\# 4$ & 1.925 & 2.061 \\
\hline$\# 5$ & 1.901 & 2.056 \\
\hline$\# 6$ & 1.898 & - \\
\hline$\# 7$ & 1.855 & - \\
\hline$\# 8$ & 1.890 & 2.051 \\
\hline$\# 1^{\text {(a) }}$ & - & 2.062 \\
\hline$\# 2^{\text {(a) }}$ & - & 2.060 \\
\hline$\# 3^{(\text {a) }}$ & - & 2.066 \\
\hline$\# 4^{(\text {a) }}$ & - & $2.060 \pm 0.005$ \\
\hline Mean $^{\text {(b) }}$ & $1.895 \pm 0.017$ & \\
\hline
\end{tabular}

*The larger sample number it has, the closer it was to the bottom of the mold.

**Same sample number for each waste does not mean that the samples were taken from same level of the mold, but refers to the relative level in the mold for each waste.

(a) Replicate specimens obtained using another PVC mold with the mixture in the same batch.

(b) Error expressed at the $95 \%$ confidence limit.

SPC waste form specimens containing phosphogypsum sand waste have similar apparent densities of approximately $1.89 \mathrm{~g} / \mathrm{cm}^{3}$, regardless of their level in the mold. Waste form specimens containing surrogate have almost the same apparent density of $2.06 \mathrm{~g} / \mathrm{cm}^{3}$ at any level within two molds. This is indicative of good homogeneity within SPC waste form specimens. Particles of phosphogypsum sand 
and surrogate calcium sulfate were observed to be homogeneously dispersed within the SPEC. No aggregation and settling were observed in the samples.

\subsection{Compressive Strength}

Compressive strength testing was performed in accordance with the standard method ASTM C-39 (Compressive Strength of Cylindrical Concrete Specimens) [11]. Results are summarized in Table 5.

Table 5. Compressive Strengths of SPC Waste Forms

\begin{tabular}{|l|l|l|}
\hline \multicolumn{1}{|c|}{ Waste Type and Loading } & $\begin{array}{c}\text { Compressive Strength, } \\
\text { psi }\end{array}$ & $\begin{array}{c}\text { Compressive Strength, } \\
\text { Mpa }\end{array}$ \\
\hline Neat $^{(\mathrm{a}, \mathrm{b})}$ & 3,616 & 24.9 \\
\hline Phosphogypsum Sand Waste, $^{(\mathrm{c})} 40 \mathrm{wt} \%$ & $3,470 \pm 287$ & $23.9 \pm 2.0$ \\
\hline Surrogate calcium sulfate ${ }^{(\mathrm{d})} 40 \mathrm{wt} \%$ & $5,135 \pm 632$ & $35.4 \pm 4.4$ \\
\hline
\end{tabular}

(a) Result reflects mean value for two specimens.

(b) Standard deviation for two specimens : $\pm 286 \mathrm{psi}( \pm 2.0 \mathrm{Mpa})$. Error expressed at $95 \%$ confidence limit for two replicate specimens : $\pm 2,571 \mathrm{psi}( \pm 17.7 \mathrm{Mpa})$.

(c) Mean value and error expressed at $95 \%$ confidence limit for four replicate specimens.

(d) Mean value and error expressed at $95 \%$ confidence limit for five replicate specimens.

The neat SPC forms containing no waste tested for this study had a mean compressive strength of 3,616 psi. This compressive strength is higher than those of neat SPC forms (approximately 1,800$2,600 \mathrm{psi}$ ) previously reported $[4,9]$. While the compressive strength of the waste form containing 40 $\mathrm{wt} \%$ surrogate increased to 5,134 psi by the addition of surrogate waste to the SPC, the compressive strength of the SPC waste form containing phosphogypsum sand waste was 3,470 psi, similar to that of neat SPC forms. The SPC waste form containing phosphogypsum sand waste had more voids than that of surrogate. Voids in the SPC waste form may be decreased by careful sample preparation. If the voids decrease, the compressive strength of the waste form will increase. Although the compressive strength of the SPC waste form containing phosphogypsum sand waste was not higher than those of the neat SPC form and the SPC waste form containing surrogate, the SPC waste form containing phosphogypsum sand waste possessed excellent mechanical integrity.

\subsection{Water Immersion Testing}

Water immersion testing was performed on three replicate specimens for SPC waste forms containing $40 \mathrm{wt} \%$ phosphogypsum sand waste and $40 \mathrm{wt} \%$ surrogate calcium sulfate, respectively. Each specimen was immersed completely in demineralized water at ambient temperature $\left(25^{\circ} \mathrm{C}\right)$ and was examined periodically. Upon completion of 90 days, they were removed from the water and checked for variation in weight and dimension. Then, compressive strength testing was conducted according to ASTM C-39. All specimens had negligible changes in weight and dimensions after 90 day water immersion. Their compressive strength was also retained after water immersion. Results are 
summarized in Table 6. Improvements of compressive strength may be attributed to experimental scatter associated with the limited sample population.

Table 6. Projected Cumulative Fractional Release of Calcium from the SPC Waste Form Containing $40 \mathrm{wt} \%$ Phosphogypsum Sand Waste

\begin{tabular}{|c|c|c|c|c|}
\hline & \multicolumn{4}{|c|}{ Projected Cumulative Fractional Release, $\%^{(\mathrm{a})}$} \\
\hline \multicolumn{1}{|c|}{ Dimension of Waste Form } & 10 years & 50 years & 100 years & 300 years \\
\hline $57 \mathrm{~cm}$ in I. D. $x$ 70 cm in height & 2.8 & 6.2 & 8.7 & 14.6 \\
\hline $1 \mathrm{~m}$ in I. D. $x$ 1 $\mathrm{m}$ in height & 1.7 & 3.8 & 5.3 & 9.2 \\
\hline $2 \mathrm{~m}$ in I. D. $x$ 2 $\mathrm{m}$ in height & 0.86 & 1.9 & 2.7 & 4.6 \\
\hline
\end{tabular}

(a) Projection was made by the diffusion model using a diffusion coefficient of $2.02 \times 10^{-10}$ $\mathrm{cm}^{2} / \mathrm{sec}$ measured at $25^{\circ} \mathrm{C}$.

\subsection{Accelerated Leach Test}

Leach testing for the SPC waste form containing phosphogypsum sand waste was conducted in accordance with Accelerated Leaching Test (ALT), developed at BNL and adopted by ASTM as Standard Test Method C-1308-95 [12, 13]. Three replicate specimens were leach tested at $25^{\circ} \mathrm{C}$. Each specimen was leached in a leachant volume that was 100 times the geometric surface area of the specimen. In this experiment, 2,900 $\mathrm{ml}$ of distilled water was used in leachant for each specimen because each specimen had a surface area of $29 \mathrm{~cm}^{2}$. It was changed twice on the first day, and then daily for 11 days. Leachate were analyzed for major elements of phosphogypsum sand waste, e.g., $\mathrm{Ca}, \mathrm{Al}, \mathrm{Fe}, \mathrm{Na}$ by ICP. Phosphorous in the leachate was checked by Hach kit.

Concentrations of $\mathrm{Al}, \mathrm{Fe}, \mathrm{Na}$, and phosphorous in the leachate were under, or near, the detection limit for all leachates so they were omitted from leach rate calculations. Calcium leach rates were calculated using a computer program that was developed to accompany the Accelerated Leach Test (the ALT program). Figure 3 shows leaching data and modeling curves for three replicate SPC waste forms containing $40 \mathrm{wt} \%$ phosphogypsum sand.

The release of calcium from SPC waste forms was very slow. Release data were in close agreement with those predicted by the diffusion model, indicating diffusion as the dominant leaching mechanism. The goodness-of-fit value of the diffusion model to the experimental data was less than $1 \%$ for all specimens. The average diffusion coefficient of calcium was $2.02 \times 10^{-10} \mathrm{~cm}^{2} / \mathrm{sec}$. It is interesting to note that release of calcium from the SPC waste form was controlled by diffusion while previous studies indicate the release of calcium from hydraulic cement waste form is probably controlled by solubility [13]. Table 6 shows the projected cumulative fraction release of calcium from the SPC waste form containing $40 \mathrm{wt} \%$ calcium as a function of waste form size after 10 years, 50 years, 100 years, and 300 years, using the average diffusion coefficient of $2.02 \times 10^{-10} \mathrm{~cm}^{2} / \mathrm{sec}$ at $25^{\circ} \mathrm{C}$ obtained from this experiment. This indicates clearly that the SPC waste form is stable and releases calcium very slowly. Releases of radioactive and hazardous contaminants are therefore also expected to be low. 


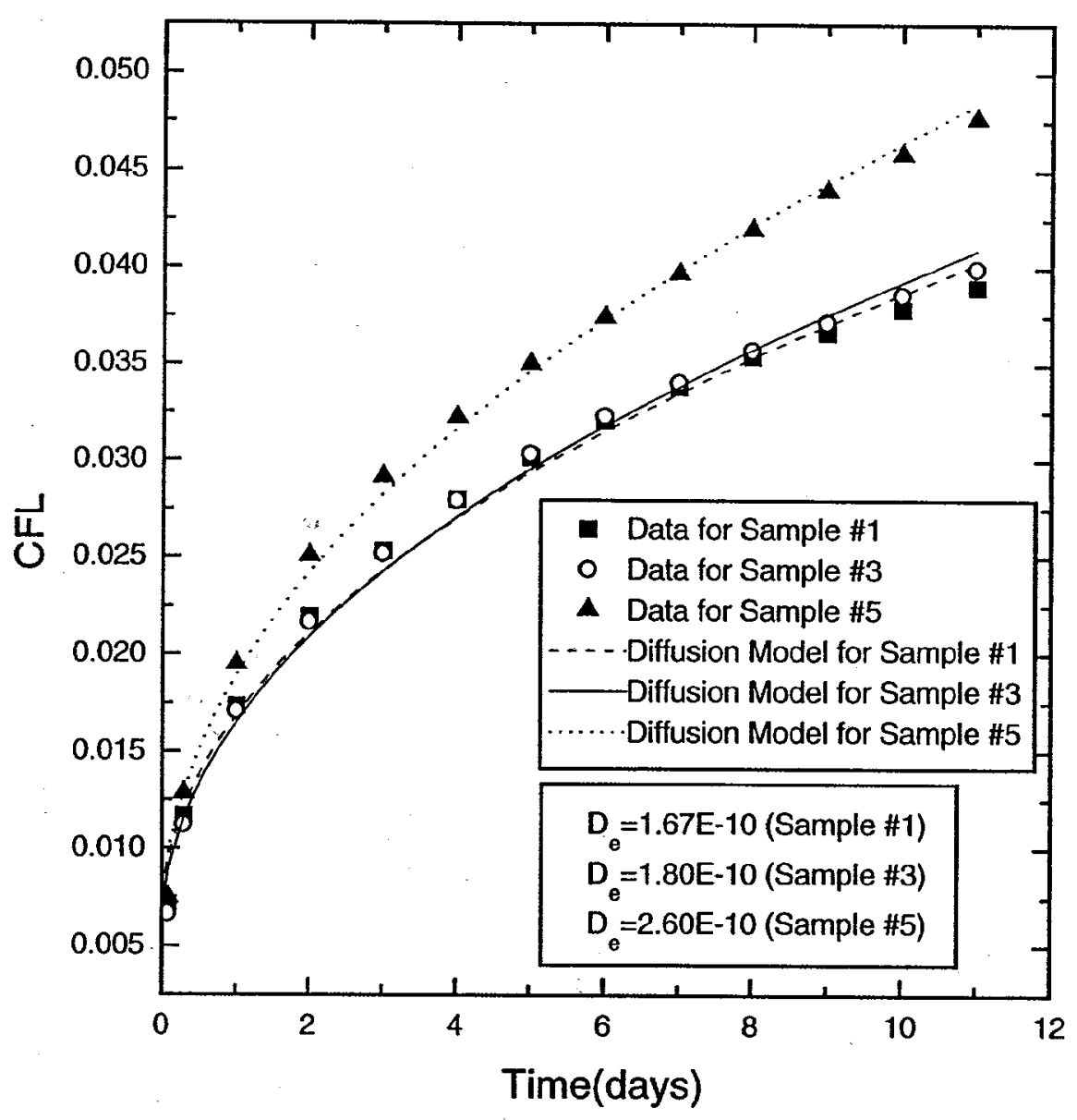

Figure 3. Leaching Data and Diffusion Model Curves for Three Replicate SPC Waste Forms Containing $40 \mathrm{Wt} \%$ Phosphogypsum Sand Waste at $25^{\circ} \mathrm{C}$ 


\section{SUMMARY AND CONCLUSIONS}

Large quantities of by-product sulfur with little commercial or social benefit are generated in Kazakstan and are currently being treated as waste. Conversion of this material to sulfur polymer will facilitate beneficial use of the material for treatment of hazardous, radioactive and mixed wastes and for various construction applications. By-product sulfur produced at Tengizchevroil oil production facilities in the Republic of Kazakstan was shipped to the U.S. and was successfully converted to SPC as evidenced by the presence of $5 \mathrm{wt} \%$ carbon detected in the SPC product. Small quantities of chromium were also detected in the Kazakhstan sulfur and SPC product (approximately 6 ppm and 12 ppm, respectively), but neither material failed TCLP testing for hazardous waste.

The Kazakstan SPC was then used to conduct a treatability study for the encapsulation of phosphogypsum waste generated in Kazakhstan as a result of fertilizer production. Process development activities resulted in maximum waste loadings of $56 \mathrm{wt} \%$, but optimal mixing and pouring was limited to mixtures containing $40 \mathrm{wt} \%$ waste. At $40 \mathrm{wt} \%$ waste loading, homogeneity was demonstrated by the close agreement of apparent density measurements throughout the waste forms. Performance testing of SPC waste forms included compression, water immersion, and accelerated leaching. Compressive strength for neat Kazakhstan SPC waste forms was about 1.5 times greater than previous data for domestic SPC. The compressive strength of SPC waste forms containing phosphogypsum sand waste was 3,470 psi, similar to that of neat SPC forms. Although the compressive strength of the SPC waste forms containing phosphogypsum sand waste was not higher than those of the neat SPC forms and the SPC waste forms containing surrogate, the SPC waste forms containing phosphogypsum sand waste possessed excellent mechanical integrity. Waste forms containing $40 \mathrm{wt} \%$ waste did not show any deterioration under saturated conditions in water immersion. Their compressive strength was also retained after water immersion. Accelerated Leach Testing revealed diffusion is the dominant leaching mechanism and projected leaching for a full size water form ( $2 \mathrm{~m}$ in diameter $\mathrm{x} 2 \mathrm{~m}$ in height) is $<5 \%$ after 300 years. 


\section{REFERENCES}

1. Sullivan T. A., and W. C. Mcbee, "Development and Testing of Superior of Sulfur Concretes,” RI-8160, Bureau of Mines, U.S. Dept. of the Interior, Washington, DC, 1976.

2. Mcbee, W. C., T. A. Sullivan, and B. W. Jong, "Modified Sulfur Cements for Use in Concretes, Flexible Pavings, Coatings and Grouts,' RI-8545, Bureau of Mines, U.S. Dept. of the Interior, Washington, DC, 1981.

3. Colombo, P., P.D. Kalb, and J.H. Heiser, "Process for the Encapsulation and Stabilization of Radioactive Hazardous and Mixed Wastes,” U.S. Patent No. 5,678,234, Oct. 14, 1997.

4. Kalb P. D., and P. Colombo, "Modified Sulfur Cement Solidification of Low-Level Waste, Topical Report,” BNL-51923, Brookhaven National Laboratory, NY, October 1985.

5. Kalb P. D., J. H. Heiser III, and P. Colombo, "Modified Sulfur Cement Encapsulation of Mixed Waste Contaminated Incineration Fly Ash," Waste Management Vol. 11, Number 3, pp.147-153, Pergammon Press, New York,1991.

6. Adams J. W., and P. D. Kalb, "Thermoplastic Stabilization of a Chloride, Sulfate, and Nitrate Salts Mixed Waste Surrogate," Proceedings of the I\&EC Special Symposium, Emerging Technologies for Hazardous Wastes, American Chemical Society, Atlanta, GA, September 19$20,1995$.

7. Kalb P. D., J. W. Adams, M. L. Meyer, and H. H. Burns, "Thermoplastic Encapsulation Treatability Study for a Mixed Waste Incinerator Off-Gas Scrubbing Solution,” Stabilization and Solidification of Hazardous, Radioactive, and Mixed Wastes, ASTM STP1240, T. M. Gilliam, and C. C. Wiles, eds., American Society for Testing and Materials, Philadelphia, PA, 1995.

8. Kalb P. D., L. W. Milian, A. J. Grebenkov, and S. P. Rutenkroger, "Thermoplastic Process Treatability for Contaminated Hearth Ash from the Republic of Belarus," Proceedings of the 1996 International Conference on Incineration and Thermal Treatment Technologies, Savannah, GA, May 6-10, 1996.

9. Kalb P. D., J. H. Heiser III, R. Pietrzak, and P. Colombo, "Durability of Incineration Ash Waste Encapsulated in Modified Sulfur Cement," Proceedings of the 1991 Incineration Conference, Knoxville, TN, May 13-17, 1991.

10. U.S. Environmental Protection Agency, "Toxicity Characteristic Leaching Procedure," 40 CFR 261, Fed. Reg. 55, 11863, March 29, 1990.

11. ASTM, "Standard Method of Test for Compressive Strength of Cylindrical Concrete Specimens," C39-72, American Society for Testing and Materials, Philadelphia, PA, 1975. 
12. Fuhrmann M., R. F. Pietrzak, J. Heiser III, E. M. Franz, and P. Colombo, "User's Guide for the Accelerated Leach Test Computer Program," BNL-52267, Brookhaven National Laboratory, Upton, NY, 11973, 1990.

13. ASTM, "Standard Method of Test for Accelerated Leach Test for Diffusive Releases from Solidified Waste and a Computer Program to Model Diffusive, Fractional Leaching from Cylindrical Waste Forms," ASTM C1308-95, American Society for Testing and Materials, West Conshohocken, PA, 1996. 